\title{
An Epidemological study on Low Back Ache (Kati Shool)
}

\author{
Research Article
}

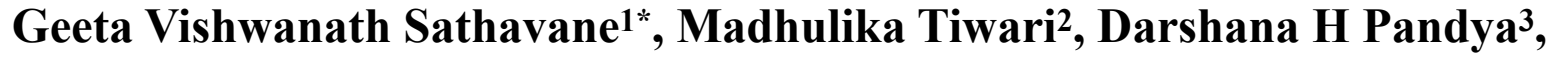 Pramod Khobragade ${ }^{4}$, Samata V Tomar 5}

\author{
1. Associate Professor, Rog Nidana Department, 2. Assistant Professor, Sharir Rachana Department \\ Datta Meghe Ayurved Medical College and Hospital, Wanadongari, Nagpur. \\ 3.Assistant Professor, Rog Nidana Department \\ Institute of Post Graduate Teaching \& Research in Ayurveda Jamnagar. \\ 4. Professor and Head, Dravayaguna Department \\ Datta Meghe Ayurved Medical College and Hospital, Wanadongari, Nagpur. \\ 5. HOD \& Professor, UG and PG Department of Agadatantra, SSAM, Nashik.
}

\begin{abstract}
The prime causative factors for all the disease is faulty life style and dietetics which is being followed frequently, leads to many diseases. Low back pain is one among them. Low back pain (Katishoola) is most expensive $\&$ benign condition in industrialized countries. It is one of the most frequent symptoms encountered by adults. The annual prevalence of LBP is $15-45 \%$. Aims and objective-To evaluate the role of dietetics \& life style modern era and working pattern in progression of low back ache. Material and method- Survey work was carried out on working group of Gujarat ayurveda university employees, OPD and IPD patients having low back ache on the basis of specially prepared proforma and questionnaires including present era lifestyle, working pattern and diet pattern. Total 91 patients were surveyed. Maximum numbers of patients were in age between 31-40 yr. The person doing mainly labour and/or clerical work, having shift and night duty, long time sitting on one place with improper posture, excessive walking ( $>3 \mathrm{hr}$ daily), bending posture, Standing type work ( $>3 \mathrm{hr}$ daily), $>2 \mathrm{hr}$ travelling daily were affected more. Vishamashana, abhishyandi aaharsevan, consuming oily food, stress, irregular bowel habit, disturbed sleep, ratrijagaran, vegdhaarana etc. were observed as nidana. Conclusion- Faulty life style and diet pattern leads to accumulation and provocation of respective dosha and development of various life style related diseases and one of them is low back ache.
\end{abstract}

Key Words: Katishool, Low back ache, Survey, Working pattern, Lifestyle.

\section{Introduction}

In present era, diseases affecting the locomotors system are seen increasingly which considerably reduces the human activity in terms of social and professional life. Now a day's human activities are totally contradictory to Swasthavritta. Regime and rules are opposite. Irregular food habit (Vishambhojana), suppression of natural urges (Vegavarodha), stress (Chinta), lack of proper sleep and relaxation being common part of life. Excessive sitting for longer time at one place, improper sitting posture during work in offices (Vishamaasana), continuous and over exertion (Atishrama), jerky movements during traveling and sports (Vishamcheshta) etc. created undue pressure to the spinal cord. Mostly above said conditions \&

\section{* Corresponding Author:}

\section{Geeta Vishwanath Sathavane}

Associate Professor

Rog Nidana Department

Datta Meghe Ayurveda Medical College and Hospital,

Wanadongari, Nagpur, India

Email Id: geeta.sathavane@gmail.com lifestyle patterns put maximum strain on spine \& lower portion of pelvis and play an important role in producing low back pain (Katishool). In this way, this disease is now becoming a significant threat to the working population.

The lifetime prevalence of non-specific (common) low back pain is estimated at $60 \%$ to $70 \%$ in industrialized countries (one-year prevalence 15\% to $45 \%$, adult incidence $5 \%$ per year). The prevalence rate for children and adolescents is lower than that seen in adults but is rising. Prevalence increases and peaks between the ages of 35 and 55. (1) Epidemiological data suggests that extreme height, cigarette smoking, morbid obesity, job dissatisfaction, work condition, legal social factor, financial stressor, emotional circumstances heavily influence back disability. Heavy physical work, weight lifting, prolong static work posture, simultaneous bending \& twisting, long time sitting on one place may lead to back pain. Men \& women are equally affected, but those female who are $>60 \mathrm{yrs}$ complain more than male.(2) In an overall assessment major number of patients presented to the hospital has some symptoms related with pain on low back and legs.

Low back pain can be compare with Katishoola which is listed as one of Vatavyadhi , in which Vata is essential causative factor. As Asthi \& Vayu are inversely 
related with each other, the aggravation Vata particularly in Aasthi hampers the quality of Asthidhatu. (3) The weak Asthidhatu provides to set the disease process \& when vitiated Vata gets settled into Katipradesh causes Katishoola. The Etiological factors and pathogenesis of above disease i.e. Katishool are not given separately in classic but being one of the 80 Nanatmaja Vatavyadhis (4) the same Nidana of Vatavyadhies is applicable here.(5) Out of 5 types of Vata, Vyana \& Apana are specially vitiated. In this condition many times Katishoola is seen alarming symptom for future disease condition like Grudhrasi, Pakwashayagata Vata(6), Gudagatavata(7) and so on.

\section{Aims and objective}

To evaluate the role of dietetics \& life style of modern era and working pattern in progression of low back ache.

\section{Materials and Methods}

Proforma and questionnaires including present era lifestyle, diet pattern and working pattern were prepared to assess the subjects.

Special survey work was carried out in working group of GAU Employees.

Total 91 patients were surveyed for the study.

\section{Selection criteria \\ Inclusion criteria}

All the subject working in GAU campus and having complaints of backache at least more than 3 months and ready to give their inform consent for the participation were selected for the present study irrespective of their age, gender and work pattern.

Patients were having complaints of LBP and came to the IPGT\&RA hospital for treatment was also selected for present survey study.

\section{Exclusion criteria}

All the subject working in GAU campus and having complaints of backache for less than 3 month and did not ready to give their inform consent for the participation were excluded for the present study.

Patients were not having complaint of LBP.

\section{Study period}

Total 91 patients were surveyed during year 2012.

\section{Observations and results}

Out of 91 patients, $38(41.76 \%)$ patients were laborer, 26(28.57\%) patients were doing clerical / computer work. and $27(29.67 \%)$ patients were housewives. (Table1)

Table1: Nature of work of 91 patients

\begin{tabular}{|c|c|c|} 
Nature of work & $\begin{array}{c}\text { Number of } \\
\text { patients }\end{array}$ & Percentage \% \\
\hline Housewife & 27 & 29.67 \\
\hline Laborer & 38 & 41.76 \\
\hline Clerical/Computer & 26 & 28.57 \\
\hline
\end{tabular}

Katishool (Low back pain) was found in 100\% of patients, Stambha (Stiffness in back) (63.74\%), Spandana (Radiating pain) (40.66\%) Ruka (constant pain in lumber region) $(36.26 \%)$ Toda (Pricking type of pain) $(10.99 \%)$ were observed as chief complaints. Gaurava( Heaviness in body) (48.35\%), Udaradhmana (Gurgling sound with fullness in abdomen) $(41.76 \%)$ Tandra (Sluggishenss) (29.67\%), Bhrama (16.48\%), Arochaka (Loss of taste) (13.19\%), Bhaktdwesha (Loss of appetite) (13.19\%) were observed as associated complaints. $35.16 \%$ patients were having symptoms from $2 \mathrm{~m}-1 \mathrm{yr}$ followed by $32.97 \%$ patients was having chronicity of $1-2$ years. Maximum no. of patients were females $(71.43 \%)$, from poor socioeconomic status $(53.85 \%)$ and belonging to age group between $31-40 y$ r (36.26\%). $46.15 \%$ were of Vatapitta Prakriti. On taking a careful history it was observed that most of the patients were not following the code and conducts described in ayurveda for healthy eating. $48.35 \%$ of patients' were daily taking fried food items (oily food). $40.66 \%$ of patients were daily taking Spicy food, daily potato in diet $(26.37 \%)$, taking Curd more than 3times in week as it is Abhishyandi in nature was observed in $25.27 \%$ and specially taking curd at night in $15.38 \%$ of patients, taking Atisheeta Ahara Sevena such as icecream $>3$ times in week. (17.58\%), frequently soft drinks $(24.18 \%)$, frequently fermented food items $(18.68 \%)$ and Junk food and were observed. Katu Rasa (pungent) dominant diet was taking $(56.04 \%)$ of patients, Followed by $37.36 \%$ were taking Madhura Rasa (sweet).Dietary habits like Vishamashana (irregularity in quantity and time of diet $(40.66 \%)$, Alpashana (taking less quantity of food) $(19.78 \%)$ Adhyashana (Taking meal on meal) (8.79\%), Viruddhashana (consuming incompatible foods) and Atimatrabhojana (taking more quantity of food than digestive fire) (6.59\%) were observed. (Table 2)

Table 2: Distribution according to dietary haibts

\begin{tabular}{|c|c|c|}
\hline Dietary habits & $\begin{array}{c}\text { Number of } \\
\text { patients }\end{array}$ & Percentage \% \\
\hline Alpashana & 18 & 19.78 \\
\hline Viruddhashana & 6 & 6.59 \\
\hline Vishamashana & 37 & 40.66 \\
\hline Atimatrabhojana & 6 & 6.59 \\
\hline Adhyashana & 8 & 8.79 \\
\hline
\end{tabular}

$82.41 \%$ of patients were habitual for tea more than thrice a day, while $31.86 \%$ of patients were taking tobacco in the form of chewing and smoking. And $3.30 \%$ of patients were Alcoholics. Disturbed appetite (Vishamagni) (36.26\%), Disturbed sleep (Khandita Nidra) (46.15\%), frequent awakening at night (Ratrijagarana) (21.98\%), Irregular bowel habit (74.72\%) was observed in patients. Diwaswapa (Day sleep) $(79.12 \%)$ Travelling more than $1 \mathrm{hr}$ daily $(51.56 \%)$ Vegadharana (Suppuration of natural urge) $37.36 \%$, working in AC (Ateesheeta) more than $5 \mathrm{hr}$ daily was observed. H/o Laparotomy (29.67), H/0 Trauma (Abhighata) (35\%), Chinta (stress) (71.43\%), Krodha (angry nature) $(28.57 \%)$ was observed in patients. 
From Working pattern, working by sitting more than $3 \mathrm{hr}$ continuously $(53.13 \%)$ and improper sitting posture $(91.18 \%)$, long standing work more than $3 \mathrm{hr}$ (60.94\%), Bending type of work more than $1 \mathrm{hr}$ $(29.69 \%)$ walking more than $2 \mathrm{hr}(42.19 \%)$ was noticed in patients. These are known risk factors for spine problems. $25 \%$ of patients having shift duty while $20 \%$ having night duty 3 times per week. (Table 3 )

Table 3: Working information of 64 employees

\begin{tabular}{|c|c|c|}
\hline Nature of work & $\begin{array}{c}\text { Number of } \\
\text { patients }\end{array}$ & Percentage \% \\
\hline Sitting & 34 & 53.13 \\
\hline Walking & 27 & 42.19 \\
\hline Standing & 39 & 60.94 \\
\hline Bending & 19 & 29.69 \\
\hline Shift duty & 16 & 25 \\
\hline Night duty & 13 & 20.31 \\
\hline
\end{tabular}

Table 4: Distribution according to working hours per day in 64 patients

\begin{tabular}{|c|c|c|}
\hline Hr/day & $\begin{array}{c}\text { Number of } \\
\text { patients }\end{array}$ & Percentage \% \\
\hline $3-5 \mathrm{hr}$ & 4 & 6.25 \\
\hline $6-8 \mathrm{hr}$ & 44 & 68.75 \\
\hline $8-12 \mathrm{hr}$ & 17 & 26.56 \\
\hline
\end{tabular}

Table 5: Sitting hours per day during working in 34 patients

\begin{tabular}{|c|c|c|}
\hline Sitting Hr/day & $\begin{array}{c}\text { Number of } \\
\text { patients }\end{array}$ & Percentage \% \\
\hline $1-3 \mathrm{hr}$ & 13 & 38.24 \\
\hline$>3 \mathrm{hr}$ & 21 & 61.76 \\
\hline
\end{tabular}

Table 6: Sitting posture during working in 34 patients

\begin{tabular}{|c|c|c|} 
Sitting posture & $\begin{array}{c}\text { Number of } \\
\text { patients }\end{array}$ & Percentage \% \\
\hline Proper & 3 & 8.82 \\
\hline Improper & 31 & 91.18 \\
\hline
\end{tabular}

Table 7: Walking hours per day during working in 27 patients:

\begin{tabular}{|c|c|c|}
\hline Hr/day & $\begin{array}{c}\text { Number of } \\
\text { patients }\end{array}$ & Percentage \% \\
\hline $1-2$ & 16 & 59.26 \\
\hline$>2 \mathrm{hr}$ & 11 & 40.74 \\
\hline
\end{tabular}

Table 8: Standing hours per day during working in 39 patients:

\begin{tabular}{|c|c|c|}
\hline Hr/day & $\begin{array}{c}\text { Number of } \\
\text { patients }\end{array}$ & Percentage \% \\
\hline $1-3 \mathrm{hr}$ & 19 & 48.72 \\
\hline$>3 \mathrm{hr}$ & 20 & 51.28 \\
\hline
\end{tabular}

Table 9: Bending hours per day during working in 19 patients:

\begin{tabular}{|c|c|c|}
\hline $\mathrm{Hr} /$ day & $\begin{array}{c}\text { Number of } \\
\text { patients }\end{array}$ & Percentage $\%$ \\
\hline$<1 \mathrm{hr}$ & 8 & 42.10 \\
\hline$>1 \mathrm{hr}$ & 11 & 57.89 \\
\hline
\end{tabular}

Most of the female patients were having past history of irregular; Scanty (oligomenorrhea), painful menses (dysmenorrhea) whereas $53.85 \%$ (35).Female patients were in menopausal stage and $3.33 \%$ of patients were having the complaint of White discharge. (Table 10)

Table10: Distribution according to menstrual history in 65 patients

\begin{tabular}{|c|c|c|}
\hline $\begin{array}{c}\text { Menstrual } \\
\text { History }\end{array}$ & $\begin{array}{c}\text { Number of } \\
\text { Patients }\end{array}$ & Percentage \% \\
\hline Regular & 23 & 76.67 \\
\hline Irregular & 7 & 23.33 \\
\hline Painful & 10 & 33.33 \\
\hline Painless & 20 & 66.67 \\
\hline Scanty & 16 & 53.33 \\
\hline Heavy & 1 & 3.33 \\
\hline Moderate & 13 & 43.33 \\
\hline Menopause & 35 & 53.85 \\
\hline White discharge & 13 & 43.33 \\
\hline
\end{tabular}

Most of patients have one and more aggravating and relieving factors. Prolong standing (52.75\%), walking (49.45\%), forward bending $(27.47 \%)$,Squatting position $(24.18 \%)$, and lifting heavy weight $(10 \%)$ were observed as aggravating factors.(Table 11)

Table 11: Distribution according to aggravating factors

\begin{tabular}{|c|c|c|}
$\begin{array}{c}\text { Aggravating } \\
\text { factors }\end{array}$ & $\begin{array}{c}\text { Number of } \\
\text { patients }\end{array}$ & Percentage \% \\
\hline Prolong standing & 48 & 52.75 \\
Walking & 45 & 49.45 \\
Squatting & 22 & 24.18 \\
\hline Lifting weight & 10 & 10.99 \\
\hline Forward. bending & 25 & 27.47 \\
\hline Winter season & 5 & 5.49 \\
\hline
\end{tabular}

Lying down position (67.03\%), sitting position $(23.08 \%)$, to have Analgesics $(9.89 \%)$ and application of medicated oil, hot fomentation locally (Snehan Swedan)(3.30\%) were observed as relieving factors in patients. (Table 12)

Table 12: Distribution according to Upashaya (Relieving factors)

\begin{tabular}{|c|c|c|}
\hline Relieving factors & $\begin{array}{c}\text { Number of } \\
\text { patients }\end{array}$ & Percentage \% \\
\hline Lying down & 61 & 67.03 \\
\hline Sitting & 21 & 23.08 \\
\hline Analgesics & 9 & 9.89 \\
\hline Snehan Swedan & 3 & 3.30 \\
\hline
\end{tabular}

\section{Discussion}

Katishool (Low back pain), Stambha (Stiffness), Spandana (Radiating pain) Ruka (constant pain) Toda (Pricking type of pain) and Udarshool (abdomen pain) were observed as chief complaint while Gaurava (Heaviness in body), Udaradhmana (Gurgling sound with fullness in abdomen) Tandra (sluggishness), Bhrama, Arochaka (Loss of taste), Bhaktdwesha (Loss of appetite) were observed as associated symptoms. This shows involvement of Vata and Kapha Dosha in 
disease samprapti. Maximum number of patients between the age group 31-50 yr. It is most active period of life in which the various excessive physical activities are performed, Intervertebral discs begin deteriorating and growing thinner by age 30. (8) Highest incidence was observed in females followed by Laborers. Their low socio-economic status is often reflected in the poor quality of their accommodation and workplace, putting them further at risk of various diseases(9) Females have variety of physical work and sustained variety of posture during household works, which puts a strain on lumbar spine(10) Also labors have to Work in different postures i.e. lift many and varied weights and have to stand or work in unusual postures for long periods which sustain higher load on their spine. These are one of the causative factors for Vata vitiation.(11) Vatakaphaja and Vaatapittaja Prakruti patients found to be more affected, it suggest that Vata plays a major role in the manifestation of the disease Samprapti. Most of patients were belonging to poor income group .Poor people are not able to take correct nutrition and hygienic diets. Due to lower education people have to do the job which is more strain full, which leads to Dhatukshaya and resulted in VataPrakopa in the form degeneration which further leads to causing the disease. Dietary habits like Vishamashana, Alpashana, Adhyashana, Viruddhashana and Atimatrabhojana was observed. Alpasana leads to Dhatukshayajanya (depletion in body elements) Vata Prakopa, while Vishamashana, Adhyashana, Viruddhashana and Atimatrabhojana are Margavarodhjanya (obstructive) causative factors of Vata Prakopa. Katurasa dominant diet was taken by majority of patients followed by Madhura rasa. Excessive Katu Rasa sevana provoks Vata.(12) Also Excessive Madhura Rasa Sevana provokes Kapha.(13) which suggest involvement of Vata and Kapha Dosha in disease Samprapti. Frequently taking Dry regime (Ruksh Anna Sevana), cold regime (Atisheetaanna sevana) fermented food items , Junk food, Abhishyandi diet such as Taking curd at night, all are responsible for Agnidushti (vitiation of digestive fire). Disturbed appetite is the outcome of Agnidushti due to Vata vitiation which is seen in most of the patients. Addiction of Tea was observed in maximum no. of patients followed by Tobacco chewing and smoking. Tea contains Kashaya Rasapradhana Dravayas and provoke Vata. Smokers are at higher risk for back problems, because smoking decreases blood circulation and affect the overall spine health.(14)

In Viharaja nidana Diwaswapa (79.12\%), Vegadharana (37.36\%), Atisheeta (9.89\%) such as working in AC were observed in most of patients which aggravates Vata by Margavarodha. While Ratrijagarana $(21.98 \%)$ causes Rukshyata in body and provocates Vata.(15). Daily Travelling $>1 \mathrm{hr}$, continuous jerks during travelling result in instability within intervertebral joints which causes spine problems. Sitting type of work $>3 \mathrm{hr}$ continuously and improper sitting posture, long time working in standing position $>3 \mathrm{hr}, \quad(60.94 \%)$, Bending type of work $>1 \mathrm{hr}$ continuously (29.69\%) was noticed. These are known risk factors for spine problems. Working in abnormal posture for long duration was the major cause of musculoskeletal morbidity (16) it put strain on ligaments and disturbs stability of intervertebral joints. (17) H/o Laparotomy such as Hysterectomy, LSCS, and Appendectomy was observed in patients. For such kind of surgery spinal anesthesia is given, Khavaigunya is created by local trauma in the form of inject able lumber anesthesia which leads to causation of disease. Chinta, Krodha, Shoka Bhaya were observed as Manasikanidana. These are the causes for Vataprakopa (18) researches shows that stressful condition of person increase $27 \%$ of pressure on the spine, it is more than enough to sub-luxate a spine and chances of occurrence of disease increases.(19) Previous history of external trauma (Abhighata) to back (Katipradesha) was reported.As it is one of the causative factors for the disease. This causes Khavaigunya in Kati Sthana and leads to further disease Samprapti. Previous traumatic back injury increases 2.5-fold risk of sciatica or Low back pain. (20)

Most of the female patients were having the History of irregular, painful menses. This shows vitiation of Apanavayu since long. Because menstruation is one of the functions of Apana Vayu. (21) Apana Vayu plays key role in formation of Samprapti of Katishoola. Most of the female patients $(53.85 \%)$ were in menopausal stage. After the menopause, chances of occurrence of Katishool increases as they lose bone density due to less absorption of calcium and ultimately osteoporotic changes.(22) Irregular bowel habit, H/o Fissure, piles, renal stone Suggest the Apana Vayu Dushti in disease. Disturb sleep due to pain indicates severity of pain. Also disturb sleep causes Vata Prakopa and it is the one of the causative factor.

Prolong standing, walking, Squatting, lifting weight etc. was seen as aggravating factors. Above said posture put more strain on the spine and increase pressure on the vertebrae and discs result in disc degeneration, low back pain and sciatica.(23) Lying down position was observed as relieving factor in maximum Patients. This posture relaxes the muscle of lumber-sacral area and the strain on lumbar spine is relieved for some time and patient feels better. (24) Chronicity of 2month-2yr was seen, this shows that patients neglect the disease in initial phase and seek medical advice when it becomes unbearable or of higher intensity. chronicity is directly proportional to the prognosis of the disease i.e. if chronicity is less prognosis is good. The prognosis of a disease depends on many factors such as the strength of Nidana the strength of aggravated Dosha the Sthana of the disease, severity of signs and symptoms, duration of the disease etc.

\section{Conclusion}

Faulty lifestyle, diet and Dietary habits Plays an important role in manifestation of Katishool. In Present study more Vayu dominant causative factors were observed, that provoked Apana and has shown symptoms of LBP. Employee and Laborers have more risk of low back pain due to their pattern of work. To 
prevent above condition people should follow healthy lifestyle and dietary habits.

\section{References}

1. https://www.who.int/medicines/areas/ priority_medicines/Ch6_24LBP.pdf dated 27/4/20

2. https://www.ncbi.nlm.nih.gov/pmc/articles/ PMC4858456/ dated 27/4/2020

3. Kaviraja Atrideva Gupta, Ashtanghrudayam of vagbhata with vidhyotani hindi commentary, Sutrasthana Doshadivighyaniya (11 /26-28), Varanasi, Chaukhambha Prakashana; Reprint 2018. $117 \mathrm{p}$

4. Vaidya Yadavaji Trikamaji, Charaka samhita of agnivesha with ayurveda deepika commentary, Sutrasthana Maharogadyaya (20/11) Varanasi, Chaukhambha surbharati Prakashana ; 2009.399p.

5. Vaidya Yadavaji Trikamaji, Charaka samhita of agnivesha with ayurveda deepika commentary, Chikitasthana, Vatavyadhichikitsa (28/15-17), Varanasi, Chaukhambha surbharati prakashana ; 2009.617p.

6. Pt. Kashinath shashtri, Charaka samhita of agnivesha with vidyotini hindi commentary, Chikitasthana,Vatavyadhichikitsa (28/28) Varanasi, Chaukhambha bharati acadamy; 2018.781p.

7. Pt. Kashinath shashtri, Charaka samhita of agniveshwith vidyotini hindi commentary, Chikitasthana,Vatavyadhichikitsa (28/26) Varanasi, Chaukhambha bharati acadamy; 2018.781p

8. https://www.preventdisease.com/diseases/ back_pain_sciatica.shtml dated on 27/4/20

9. Regmi PR, van Teijlingen E, Mahato P, Aryal N, Jadhav N, Simkhada P, et al. The health of Nepali migrants in India: A qualitative study of lifestyles and risks. Int J Environ Res Public Health 2019; 16(19).

10. Sciaticahttp://www.healthcommunities.com/ sciatica/sciatica-overview.shtml

11. Vaidya Yadavaji Trikamaji, Charaka samhita of Agnivesha with ayurveda deepika commentary, Chikitasthana,Vatavyadhichikitsa (28/15-17) Varanasi, Chaukhambha surbharati prakashana; 2009. 617p.

12. Vaidya Yadavaji Trikamaji ,Charaka samhita of Agnivesha with ayurveda deepika commentary,
Sutrasthana Atreyabhadrakapiya (26/42-4) Varanasi, Chaukhambha surbharati Prakashana; 2009.506p.

13. Vaidya Yadavaji Trikamaji, Charaka samhita of Agnivesha with Ayurveda deepika commentary, Sutrasthana Atreyabhadrakapiya (26/42-1) Varanasi, Chaukhambha surbharati prakashana; 2009.504p.

14. http://preventdisease.com/diseases/ back_pain_sciatica.shtml, dated on 22/3/2013

15. Vaidya Yadavaji Trikamaji ,Charaka samhita of agnivesha with Ayurveda deepika commentary, Sutrasthana, Ashtoninditiyadhyaya (21/50) Varanasi, Chaukhambha surbharati prakashana; 2009.119p.

16. Khanam N, Wagh V, Gaidhane AM, Quazi SZ. Assessment of work-related musculoskeletal morbidity, perceived causes and preventive activities practiced to reduce morbidity among brick field workers. Ind J Community Health 2019;31(2):213-219.

17. Hedman TP, Fernie GR. Mechanical response of the lumbar spine to seated postural loads. Spine (Phila $\mathrm{Pa}$ 1976) 1997;22:734-743. [PubMed] [Google Scholar]

18. Vaidya Yadavaji Trikamaji ,Charaka samhita of Agnivesha with ayurveda deepika commentary, Chikitsasthana, Jwarchikitsadhyaya (3/115) Varanasi, Chaukhambha surbharati prakashana; $2009.407 \mathrm{p}$

19. http://www.maximizedliving.com/Home/ MaximizedLivingBlog/tabid/772/Article/406/ emotional- stress-and- your-spine.aspx, dated on $27 / 4 / 2020$

20. Determinants of sciatica and low-back pain, Pubmed http://www.ncbi.nlm.nih.gov/pubmed/ 1830689 , assessed on 27/4/2020

21. Kaviraja Atrideva Gupta, Ashtanghrudayam of vagbhata with vidhyotani hindi commentary, Sutrasthana Doshabhediya (12 /9), Varanasi, Chaukhambha prakashana; Reprint 2018. 121p

22. http://preventdisease.com/diseases/ back_pain_sciatica.shtml, assessed on 27/4/2020

23. http://www.gpnotebook.co.uk/simplepage.cfm? $\mathrm{ID}=127205363 \&$ linkID $=58819 \&$ cook $=$ no\&mentor $=1$

24. http://relievinglowerbackpain.com/2011/04/20/3sleep-positions-to-relieve-back-and-sciatica-pain-4/ 